\title{
Measuring ventilation in different typologies of rural Gambian houses: a pilot experimental study
}

\author{
Jakob B. Knudsen ${ }^{1 *} \mathbb{D}$, Margaret Pinder ${ }^{2,3}$, Ebrima Jatta ${ }^{3,5}$, Musa Jawara², Mahamed A. Yousuf',
} Amalie T. Søndergaard ${ }^{1}$ and Steve W. Lindsay ${ }^{3,4}$

\begin{abstract}
Background: African houses are frequently too hot and uncomfortable to use a bed net at night. Indoor thermal comfort is often evaluated by measuring temperature and humidity, ignoring ventilation. This study explored ways to measure ventilation in single-roomed rural Gambian houses during the malaria transmission season and evaluated building designs that could increase airflow at night and help keep the occupants comfortable.

Methods: Two identical mud-walled houses were constructed with a metal roof, three doors and closed eaves. Experiment 1 compared five methods for measuring ventilation in a building: (1) using a blower door, (2) increasing carbon dioxide $\left(\mathrm{CO}_{2}\right)$ levels indoors using an artificial source of $\mathrm{CO}_{2}$ and then measuring the rate of gas decay, (3) using a similar approach with a natural source of $\mathrm{CO}_{2}$, (4) measuring the rise of $\mathrm{CO}_{2}$ when people enter a building and (5) using hot-wire anemometers. Experiment 2 used $\mathrm{CO}_{2}$ data loggers to compare ventilation in a reference metalroofed house with closed eaves and badly-fitting doors with a similar house with (1) thatched roof and open eaves, (2) eaves tubes, (3) screened doors and (4) screened doors and windows.
\end{abstract}

Results: In experiment $1, \mathrm{CO}_{2}$ data loggers placed indoors in two identical houses showed similar changes in airflow $(p>0.05)$ for all three methods recording either decreasing or increasing $\mathrm{CO}_{2}$. Blower doors were unable to measure airflow in houses with open eaves or screened windows and the anemometers broke down under field conditions. In experiment 2, open eaves in thatched houses, screened doors alone, and screened doors and windows increased indoor ventilation compared to the reference metal-roofed house with closed eaves and badly fitting doors $(p<0.05)$. Eaves tubes did not increase ventilation in comparison to the reference house.

Conclusion: $\mathrm{CO}_{2}$ data loggers proved to be a simple and efficient method for measuring ventilation in rural houses at night. Ventilation of metal-roofed houses can be improved by adding two screened doors and windows on opposite walls. Improved ventilation will result in increased thermal comfort making it more likely that people will sleep under a bed net.

Keywords: Ventilation, Airflow, Housing, Malaria, The Gambia

\footnotetext{
*Correspondence: jknud@kadk.dk

${ }^{1}$ Schools of Architecture, Design and Conservation, The Royal Danish

Academy of Fine Arts, Philip de Langes Allé 10, 1435 Copenhagen K, Denmark

Full list of author information is available at the end of the article
}

\section{Background}

Between 2019 and 2050 the population of Africa will have almost doubled [1]. This is equivalent to combining the current population of India and Africa in 30 years. Assuming that a third of the current housing stock has to be rebuilt during the same period [2], homes for up to 2 billion people will need to be built by 2050

(c) The Author(s) 2020. This article is licensed under a Creative Commons Attribution 4.0 International License, which permits use, sharing, adaptation, distribution and reproduction in any medium or format, as long as you give appropriate credit to the original author(s) and the source, provide a link to the Creative Commons licence, and indicate if changes were made. The images or other third party material in this article are included in the article's Creative Commons licence, unless indicated otherwise in a credit line to the material. If material is not included in the article's Creative Commons licence and your intended use is not permitted by statutory regulation or exceeds the permitted use, you will need to obtain permission directly from the copyright holder. To view a copy of this licence, visit http://creativeco mmons.org/licenses/by/4.0/. The Creative Commons Public Domain Dedication waiver (http://creativecommons.org/publicdomain/ zero/1.0/) applies to the data made available in this article, unless otherwise stated in a credit line to the data. 
to accommodate this growing population. To put this in perspective, that is equivalent to building housing for 7000 people per hour for the next 30 years to keep up with the population growth.

Sub-Saharan Africa's economies have been growing rapidly in the past 20 years [3], and the region has witnessed an increase in improved housing [2]. This is good news as better houses are associated with less malaria [4]. One of the biggest changes in house design is the replacement of thatched-roofs with metal-roofs. During this process the eaves are often closed which is good for reducing mosquito entry [5] and the metal-roofs also seems to reduce survivorship of indoor-resting mosquitoes [6] as they make the building hotter during daytime. But closing of the eaves might also reduce indoor comfort as it reduces ventilation in a house $[7,8]$.

Indoor climatic comfort is important since if it is too hot and there is little, if any, ventilation, it is likely to reduce the number of people sleeping under a longlasting insecticidal net (LLIN) [9] which is one of the most effective malaria control tools available [10]. The fundamental problem of designing a good house in the hot-humid tropics is one of attempting to achieve two apparently contradictory goals: to keep mosquitoes out of the house, while at the same time, maximizing the indoor ventilation in order to keep the occupants comfortable [11].

So far, there has only been one previous study that has measured ventilation or airflow in traditional African houses. This was carried out in Uganda where carbon dioxide $\left(\mathrm{CO}_{2}\right)$ ice was left to evaporate inside a house and, after reaching a maximum concentration, the rate of decline measured using a hand-held infrared $\mathrm{CO}_{2}$ analyser [12]. The rate of $\mathrm{CO}_{2}$ decline was greater in well- ventilated houses compared with poorly ventilated houses. Whilst this was an efficient method, two people remained indoors during the measurements, which is potentially unsafe and would have affected the readings since their $\mathrm{CO}_{2}$ production would vary at different indoor temperatures [13, 14]. Moreover, in many parts of subSaharan Africa the storage of $\mathrm{CO}_{2}$ ice in hot and remote areas is impracticable, as is the more sophisticated methods using radioactive tracer gases [15]. In the present study, five methods for evaluating indoor ventilation were tested. Firstly, a blower door was used which is typically used for measuring airtightness in houses in Europe and North America [16, 17]. The rectangular blower door fits tightly over an existing door gap and blows air into the room through a large fan until the pressure is constant. Ventilation, or air change rate, is typically measured as Air Exchange per hour $(\mathrm{ACH})$, which can be calculated knowing the volume of the house and the airflow the fan has to produce in order to reach a certain pressure for the whole building. Secondly and thirdly, the rate of $\mathrm{CO}_{2}$ decline was measured in buildings by increasing $\mathrm{CO}_{2}$ levels using a gas cylinder or human subjects, removing the source, and measuring the rate of $\mathrm{CO}_{2}$ decline using data loggers. Fourthly, the natural rise in $\mathrm{CO}_{2}$ levels indoors was measured when human subjects were introduced to the building. Finally, a hot-wire anemometer, designed to measure air flow at low speeds was tested.

In rural Gambia, there are distinct typologies of housing with traditional houses characterized by having mud walls, thatched roofs and open eaves, whilst modern houses have mud or cement block walls, metal roofs and closed eaves. In the RooPfs study [18], that was designed to reduce the incidence of clinical malaria in children, traditional single room mud-walled houses were modified to have metal roofs, closed eaves, with mosquito screened windows and screened doors to increase indoor air flow, to keep the occupants cooler. It is not known, however, how these architectural features affect $\mathrm{ACH}$ and indoor air speed (IAS). Indoor thermal comfort is obtained when a specific combination of temperature, humidity and IAS occurs $[19,20]$. Whilst it is simple to measure temperature and humidity using standard data loggers, measuring $\mathrm{ACH}$ and IAS remains a challenge, particularly in poor rural housing in the tropics and subtropics [21]. The primary objectives of the present study were to determine an appropriate method(s) for measuring ventilation in rural African houses and then to use these method(s) to find out whether changes in building design to increase ventilation, did actually increase ventilation.

\section{Methods}

\section{Study design}

Two experiments were conducted in rural Gambia using two houses of an identical size and shape. The first experiment was designed to determine what methods could be used for measuring indoor airflow in two houses with metal roofs, closed eaves and badly-fitting doors. The second experiment used these methods to compare indoor airflow in the reference house in comparison with an alternative design. The study was carried out from 1st July 2017 to 18th August 2017, during the beginning of the rainy season, when high numbers of mosquitoes are present [8].

\section{Study area}

The study site was at the Medical Research Council Unit The Gambia's field station at Wali Kunda $\left(13^{\circ} 34.440^{\prime} \mathrm{N}\right.$, $\left.14^{\circ} 55.471^{\prime} \mathrm{W}\right)$ on the south bank of the River Gambia in Lower Fulladu West, Central River Region, in The Gambia (Additional file 1: Figure S1). This is an area of open Sudanian savanna with extensive rice irrigation nearby. 
There is an intense rainy season from June to November, followed by a long dry season. Most clinical malaria occurs between October and December [22].

\section{Experimental houses}

Two experimental houses, positioned on a north-west to south-east axis, were constructed $10 \mathrm{~m}$ apart and $10 \mathrm{~m}$ clear of other constructions and vegetation on all sides. Houses were the average size of a single-roomed house in rural Gambia, obtained from a survey of 400 randomly selected houses in the Upper River Region of The Gambia [8]. The external base of each house was $4.20 \mathrm{~m} \times 4.20 \mathrm{~m}$ in area and the $2.20 \mathrm{~m}$ high walls were constructed from sun-baked mud-blocks (each $16 \mathrm{~cm}$ high $\times 20 \mathrm{~cm}$ wide $\times 32 \mathrm{~cm}$ long), with a front and back door on opposite sides, perpendicular to the line of houses, each $175 \mathrm{~cm}$ high and $75 \mathrm{~cm}$ wide. The only non-traditional building components were reinforced concrete ringbeams ( $20 \mathrm{~cm}$ high) on top of the wall, which were added to prevent the mud-blocks cracking when the heavy roofs were moved, and the metal profiles used to construct the roof frame.

The study was explained in the local language to male villagers and healthy volunteers, aged over 15 years who provided signed-witnessed consent, were recruited to the study. Two volunteers in each house slept in separate beds under an intact long-lasting insecticidal net (Olyset, Sumitomo Chemical, Japan) from 21:00 h to 06:00 h.

\section{House typologies}

There were five typologies of single-roomed houses used in the study (Fig. 1). Firstly, the most common typology of housing in rural Gambia is a metal-roofed house with closed eaves and two badly-fitting doors served as the reference (MCB). Secondly, the traditional Gambian house with a thatched-roof, open eaves and two badly-fitting doors (TOB). Thirdly, a metal-roofed house with closed eaves, two badly-fitting doors and four eaves tubes (MCBE). Fourthly, a metalroofed house with closed eaves and two screened doors (MCS). Lastly, a design based on a ventilated house used in the RooPfs trial [18], which had a metal-roof, closed eaves, two screened doors and screened windows (MCSG).

Houses with open eaves had a $3 \mathrm{~cm}$ gap between the top of the wall and the roof and those with closed eaves were blocked with a mixture of broken mud blocks and clay mortar. Traditional doors were constructed from a single panel of corrugate galvanized steel pinned to a wooden frame $(2 \mathrm{~cm} \times 2 \mathrm{~cm})$. To simulate poorly-fitting doors, which are common in villages, we made a $2 \mathrm{~cm}$ gap along the top and bottom of each door. Screened doors were made of $25 \mathrm{~mm}$ square steel profiles treated with anti-corrosion paint. Two screened panels made from polyester netting $(2 \times 2 \mathrm{~mm}$ mesh) (Additional file 1: Figure S3) were placed at the top and bottom of the door, each $75 \mathrm{~cm}$ wide and $60 \mathrm{~cm}$ high and fixed to the steel frame with flat bars and bolts. Both houses had a third door with an extra tightly-fitting steel door mounted with rubbers seals in order to prevent any ventilation around the door. Eave tubes were locally made from $15 \mathrm{~cm}$ diameter polyvinyl chloride pipes with polyester netting $(2 \times 2 \mathrm{~mm}$ mesh). Four eave tubes were placed at a height of $180 \mathrm{~cm}$ on each of the two facades without gables. The ventilated metalroofed house had two screened doors and two triangular screened windows $(200 \mathrm{~cm}$ wide and $45 \mathrm{~cm}$ high at the apex), constructed with wooden frames $(50 \mathrm{~mm} \mathrm{x}$ $50 \mathrm{~mm}$ ) and mosquito screening, and positioned in the gable ends of the building. Thatched roofs were pyramidal in shape and $3.6 \mathrm{~m}$ high and metal roofs, saddle shaped and $3.1 \mathrm{~m}$ high. The houses with thatched roofs had an internal volume of $37 \mathrm{~m}^{3}$ and the metal roof houses had $38 \mathrm{~m}^{3}$. Floors were beaten mud.

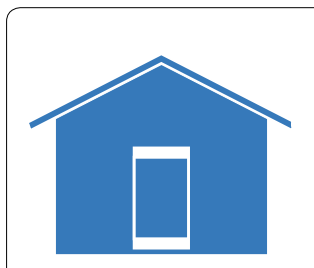

$1 \mathrm{MCB}$

Metal Closed eaves Badly fitting doors

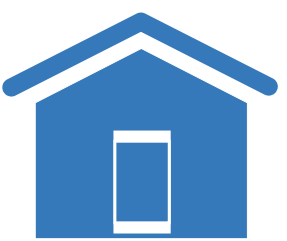

2 TOB

Thatched Open eaves Badly fitting doors

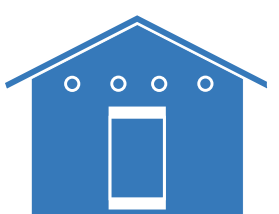

3 MCBE

Metal

Closed eaves Badly fitting doors Eave tubes

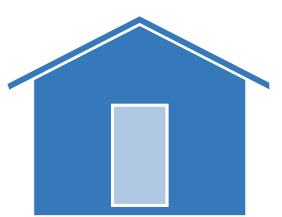

4 MCS

Metal

Closed eaves

Screened doors

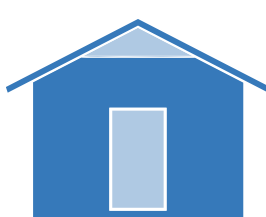

5 MCSG

Metal

Closed eaves Screened doors Gable windows

Fig. 1 House typologies 


\section{Experiment 1.Ventilation tests}

Four methods for measuring $\mathrm{ACH}$ and one method for measuring IAS were tested.

\section{Method A. Fan pressurization (blower door test)}

$\mathrm{ACH}$ was estimated using a standard blower door (Model DB B, BlowerDoor, Serial \#DB-CE1475, calibrated 17.10.2016, Certificate 8-DB-CE1475-10-17-16, The Energy Conservatory, Minneapolis, USA), based on a standard methodology $[16,17,23]$. The tightly-fitting steel door was opened for this experiment only and the blower door fitted in the door-opening (Additional file 1: Figure S3). In an empty house, the blower door was activated in order to create and maintain a pressure across the building shell, and the flow through the fan measured. Air leakage through the building was calculated and evaluated using the American Society for Testing and Materials method E779-19 [16]. The building leakage is usually defined by ACH50, the amount of air that escapes a building in $\mathrm{m}^{3} / \mathrm{h}$ when exposed to a positive or negative pressure of $50 \mathrm{~Pa}$. In order to get a precise curve for the determination of the ACH50 a minimum of five target building pressures of $5 \mathrm{~Pa}, 10 \mathrm{~Pa}, 15 \mathrm{~Pa}, 20 \mathrm{~Pa}$ and $50 \mathrm{~Pa}$ was used. The test procedure requires both a depressurization and a pressurization test to be performed, giving a total of 10 measurement points for each final ACH50 value (Additional file 1: Figure S4). During an automated process a large fan in the blower door is either pulling or pushing air in or out of the building while measuring the positive or negative pressure via a pressure gauge. The two measurements are often similar but might differ if openings in the building are working as unidirectional valves. The experiment was carried out six times through a 24-hour cycle; at $02.00 \mathrm{~h}, 06.00 \mathrm{~h}, 10.00 \mathrm{~h}, 14.00 \mathrm{~h}$, $18.00 \mathrm{~h}$ and $22.00 \mathrm{~h}$. Each test took approximately $15 \mathrm{~min}$ including moving the blower door from one house to the other. The experiment was made on the same day as method B.

\section{Method B. Artificial $\mathrm{CO} 2$ elevation \& decay}

Here $\mathrm{CO}_{2}$ levels were elevated using compressed gas and the rate of decay used to estimate $\mathrm{ACH}[12,24,25]$. All ventilation openings including windows, open eaves and gaps in doors were sealed and all people vacated the room. A $10 \mathrm{~mm}$ diameter plastic hose hung from the ceiling, $180 \mathrm{~cm}$ from the ground, was connected to a $\mathrm{CO}_{2}$ gas canister kept outside the house. $\mathrm{CO}_{2}$ was released at a rate of at $500 \mathrm{ml} / \mathrm{min}$ for approximately $60 \mathrm{~s}$ while $\mathrm{CO}_{2}$ levels inside the house was measured from the outside using the software HOBOmobile connecting the $\mathrm{CO}_{2}$ data loggers to an Iphone via Bluetooth. In this experiment and all those measuring $\mathrm{CO}_{2}$ (Methods $\mathrm{B}, \mathrm{C}$ and $\mathrm{D}$ ), $\mathrm{CO}_{2}$ data loggers $\left(\mathrm{HOBO}^{\circledR} \mathrm{MX} \mathrm{CO} 2\right.$ Logger \#MX1102,
Onset Computer Corporation. 470 MacArthur Blvd., Bourne, MA 02532, USA) were placed inside in the middle of the room, one metre above the ground. When a steady state of $\mathrm{CO}_{2}$ of 2000-3000 ppm was reached indoors, the $\mathrm{CO}_{2}$ was manually mixed by waving a $30 \mathrm{~cm}$ diameter plastic lid for $60 \mathrm{~s}$. While this was done a second person outside the building ensured the safety of the person in the room. After manually mixing the $\mathrm{CO}_{2}$, the room was left empty for $20 \mathrm{~min}$ for the air to equilibrate before opening all sealed ventilation openings and starting the measurements. Temperature, relative humidity and $\mathrm{CO}_{2}$ were measured every $5 \mathrm{~s}$ for approximately 15 min (approximately 180 measurements) on both data loggers or until the $\mathrm{CO}_{2}$ concentration indoors has declined to values near to that outdoors. The experiment was carried out six times through a 24-h cycle; at $04.00 \mathrm{~h}$, $08.00 \mathrm{~h}, 12.00 \mathrm{~h}, 16.00 \mathrm{~h}, 20.00 \mathrm{~h}$ and $00.00 \mathrm{~h}$. Each test took approximately $30 \mathrm{~min}$.

\section{Method C. Natural $\mathrm{CO}_{2}$ elevation and decay}

This experiment was similar to the proceeding one, but with $\mathrm{CO}_{2}$ levels raised through human activity, based on previous methodology [12, 25, 26]. All ventilation openings including windows, open eaves and gaps around doors were sealed. Three people walked around inside each house for $20 \mathrm{~min}$ or until the expected baseline $\mathrm{CO}_{2}$ level of $400-600 \mathrm{ppm}$ was raised to $700-800 \mathrm{ppm}$, whereupon all people left the house and all sealed ventilation openings opened. Temperature, relative humidity and $\mathrm{CO}_{2}$ were measured every $3 \mathrm{~min}$ for $8 \mathrm{~h}$ (approximately 160 measurements) on both data loggers or until the indoor $\mathrm{CO}_{2}$ concentration decreased to values similar to those outdoors, whichever occurred first. The experiment started at $09.00 \mathrm{~h}$ and ended at $17.00 \mathrm{~h}$.

\section{Method D. Natural $\mathrm{CO}_{2}$ rise}

This experiment measured the rate at which $\mathrm{CO}_{2}$ increased indoors due to human activity and was based on methods developed previously $[25,26]$. At the start of the experiment the doors were opened for $30 \mathrm{~min}$ to ventilate the house. Two people slept indoors under a LLIN inside the house from $21.00 \mathrm{~h}$ to $06.00 \mathrm{~h}$ the following morning. Sleepers only left the room under exceptional circumstances. All ventilation openings remained open and temperature, relative humidity and $\mathrm{CO}_{2}$ were measured on both data loggers every $3 \mathrm{~min}$ for approximately $9 \mathrm{~h}$ (approximately 180 measurements). The experiment was carried out daily for 6 days and made on the same day as method $C$ and $E$.

\section{Method E. Hot wire thermo-anemometer}

Here a hot wire thermo-anemometer was used to measure indoor air speed (IAS) based on an established 
methodology [27]. Two hot wire thermo-anemometers (ATP Instrumentation AAVM-8880 Hot Wire USB Logging Thermo-Anemometer, ATP Instrumentation Ltd, Ashby-de-la-Zouch, Leicestershire, United Kingdom) were placed inside the building on a tripod in the middle of the room, one metre above the ground. $\mathrm{A} \mathrm{CO}_{2}$ data logger, which also record temperature and relative humidity, was placed just below the anemometer. All doors were opened for $30 \mathrm{~min}$, ventilating the house. The internal air volume and surface area of all openings were calculated. Two adult men slept under a LLIN in each house from $21.00 \mathrm{~h}$ to $06.00 \mathrm{~h}$. From 22.00 to $06.00 \mathrm{~h}$ they were instructed to rest or sleep under a LLIN. All ventilation openings were open. IAS, $\mathrm{CO}_{2}$, relative humidity and temperature were measured every $3 \mathrm{~min}$ for approximately $9 \mathrm{~h}$ (approximately 180 measurements). The experiment was repeated for six consecutive days and made on the same day as method C and D.

\section{Experiment 2. Comparisons of $\mathrm{ACH}$ between housing typologies}

Firstly, ventilation was compared in a reference metalroofed house with closed eaves and badly-fitting doors (MCB) with a similar house (MCB). Secondly the reference metal-roofed house with closed eaves and badlyfitting doors (MCB) was compared with: (1) a house with thatched roof and open eaves and badly-fitting doors (TOB), (2) a metal-roofed house with closed eaves and badly-fitting doors plus eaves tubes (MCBE), (3) a metalroofed house with closed eaves and screened doors (MCS) and (4) a metal-roofed house with closed eaves, screened doors and screened gable windows (MCSG). All five test methods described under experiment 1 were repeated on each pair of houses for six consecutive days.
The indoor mean temperature and humidity was measured over six nights in each house typology.

\section{Statistical analysis}

For method A, mean $\mathrm{ACH}$ was determined using the six $\mathrm{ACH} 50$ values generated by the blower door software. For method B, C and D, ACH was determined using the natural logarithm $\mathrm{CO}_{2}$ concentration plotted over time. The slope of the line represented the $\mathrm{ACH}$. Each test was done 5 times (method B) or 6 times (method $C$ and D) and the mean calculated. For method $\mathrm{E}, \mathrm{ACH}$ was calculated knowing the IAS $(\mathrm{m} / \mathrm{s})$, the volume of the building $\left(\mathrm{m}^{3}\right)$ and the area of openings $\left(\mathrm{m}^{2}\right)$. Six repeated tests were carried out over a 24-h cycle for each house and the mean value calculated. Comparisons between $\mathrm{ACH}$ values determined for each house each night were made using paired $t$ tests to adjust for variation between nights. All analyses were performed using IBM SPSS v24 software.

\section{Ethical considerations}

The study was approved by the Gambia Government/ Medical Research Council's joint ethics committee (16th May 2016 and 16th March 2017) and the Department of Biosciences ethics committee, Durham University, UK (13th May 2016 and 29th June 2017).

\section{Results}

\section{Experiment 1. Ventilation tests}

The blower door test showed that there were significant differences in the $\mathrm{ACH}$ in two identical houses (Table 1). The standard test, however, requires a pressure of $50 \mathrm{~Pa}$, but due to leakages in the houses it was only possible to achieve a pressure of $25 \mathrm{~Pa}$ in the reference metal-roofed

Table 1 Experiment 1: Ventilation estimated using different methods in two identical houses

\begin{tabular}{|c|c|c|c|c|c|c|c|}
\hline \multirow[t]{2}{*}{ Method } & \multirow[t]{2}{*}{ Day } & \multirow[t]{2}{*}{ Time of recordings } & \multirow[t]{2}{*}{$\mathbf{n}$} & \multicolumn{2}{|l|}{ House } & \multirow[t]{2}{*}{$\mathbf{t}$} & \multirow[t]{2}{*}{$\mathbf{p}$} \\
\hline & & & & $\begin{array}{l}\text { House } 1 \text { Mean ACH } \\
\mathrm{m}^{3} / \mathrm{h}(95 \% \mathrm{Cl})\end{array}$ & $\begin{array}{l}\text { House } 2 \text { Mean ACH } \\
\mathrm{m}^{3} / \mathrm{h}(95 \% \mathrm{Cl})\end{array}$ & & \\
\hline Method A: Fan pressurization (blower door test) & 1 & $\begin{array}{l}02.00 \mathrm{~h}, 06.00 \mathrm{~h}, \\
10.00 \mathrm{~h}, 14.00 \mathrm{~h}, \\
18.00 \mathrm{~h} \text { and } \\
22.00 \mathrm{~h}\end{array}$ & 5 & $71.6(69.0,74.3)$ & $85.2(80.6,89.9)$ & -15.2 & $<0.001$ \\
\hline Method B: Artificial $\mathrm{CO}_{2}$ elevation and decay & 1 & $\begin{array}{l}04.00 \mathrm{~h}, 08.00 \mathrm{~h}, \\
12.00 \mathrm{~h}, 16.00 \mathrm{~h}, \\
20.00 \mathrm{~h} \text { and } \\
00.00 \mathrm{~h}\end{array}$ & 5 & $-33.2(-51.6,-14.8)$ & $-29.9(-47.2,-12.7)$ & -0.421 & 0.695 \\
\hline Method C: Natural $\mathrm{CO}_{2}$ elevation and decay* & $2-7$ & $09.00-17.00 h$ & 6 & $-28.0(-46.6,-9.5)$ & $-20.5(34.1,-6.9)$ & -1.040 & 0.346 \\
\hline Method D: Natural $\mathrm{CO}_{2}$ rise & $2-7$ & $21.00-06.00 \mathrm{~h}$ & 6 & $14.8(12.1,17.5)$ & $13.2(12.1,14.4)$ & 1.465 & 0.203 \\
\hline Method E: Hot wire thermo-anemometer & $2-7$ & $21.00-06.00 \mathrm{~h}$ & 6 & $\mathrm{n} / \mathrm{a}$ & $\mathrm{n} / \mathrm{a}$ & - & - \\
\hline
\end{tabular}

$A C H$ air exchange per hour, $\mathrm{Cl}$ confidence intervals

* First 15 min after human subjects have entered the house 
house (MCB) or the metal-roofed house with eave tubes (MCBE). For the other house typologies, it was impossible to achieve even the minimum pressure of $5 \mathrm{~Pa}$ the test requires. The three methods used for measuring $\mathrm{CO}_{2}$ indoors all showed consistent results between the two houses. Both hot wire thermo-anemometers broke during the initial test runs resulting in no data being collected.

\section{Experiment 2. Comparisons of $\mathrm{ACH}$ between housing typologies}

$\mathrm{ACH}$ was higher in houses with thatched-roofs and open eaves (TOB), and metal-roofed houses with screened doors (MCS), and metal-roofed houses with screened doors and screened windows in the gable ends (MCSG) compared with the reference metal-roofed house (MCB) assessed using three different methods for measuring changes in indoor $\mathrm{CO}_{2}$ levels (Table 2). There was, however, no difference in $\mathrm{ACH}$ between metal-roofed houses with eaves (MCBE) and the reference metal-roof house (MCB). All results in experiment 2 came from the three $\mathrm{CO}_{2}$ methods, as both the blower door test and the hot wire thermos-anemometers failed. A nightly summary of these findings is shown in Additional file 2: Table S1.

All houses showed similar patterns with highest temperature in the evening dropping gradually over night (Fig. 2). Relative humidity showed the opposite pattern with raising values over during the night. Metal-roof houses with eaves tubes (MCBE) and metal-roof houses with screened doors (MCS) were cooler than the reference MCB house in the periods before and after midnight (Table 3). The coolest houses were those with thatch roof and open eaves (TOB) or metal-roof houses with screened doors and gable windows (MCSG), and were $1.5^{\circ} \mathrm{C}$ cooler than the reference house (MSB).

\section{Discussion}

The findings demonstrate that ventilation can be measured in a range of housing typologies common in rural sub-Saharan Africa using a variety of different methods. Although the blower door is an industrial standard used to evaluate how airtight a building is, buildings with open eaves or large areas of screening were too leaky to make recordings. The blower door is designed to measure building leakage through small cracks and openings, but our buildings, with high levels of leakage, could not reach the minimum pressure required of $25 \mathrm{~Pa}$. A larger and more powerful version, however, might have been able to work. All methods that measured rising or falling levels of $\mathrm{CO}_{2}$ using data loggers to estimate ventilation in Gambian houses performed well. Raising $\mathrm{CO}_{2}$ levels indoors using gas released from a $\mathrm{CO}_{2}$ cylinder, was easy to use, cheap ( $<\$ 1 /$ test $)$ and could easily be adapted to use for testing of $\mathrm{ACH}$ in around $30 \mathrm{~min}$. It should be recognized, however, that high concentrations of $\mathrm{CO}_{2}$ are potentially lethal and that the house should be well ventilated before allowing people to return to a house after a test has been made. Raising $\mathrm{CO}_{2}$ concentrations naturally using people indoors, was simple to use and worked well. It took $20 \mathrm{~min}$ or less before a sufficiently high concentration of $\mathrm{CO}_{2}$ was obtained. With this method there is no danger of fatalities as $\mathrm{CO}_{2}$ concentrations are relatively low and measurement needs only to be taken for $15 \mathrm{~min}$ to obtain a reading. Measuring the natural rate of $\mathrm{CO}_{2}$ increase indoors, was simple to perform and worked well in poorly ventilated buildings, but failed to increase in well-ventilated structures. The hot wire thermo-anemometers performed badly in the field. Although staff were well instructed in handling the equipment both instruments broke after a few days use. The fragility of the instruments makes it very difficult to recommend hot wire thermo-anemometers for evaluating AIS under field conditions. Hot-wire thermo-anemometers can be used successfully to evaluate airflow in very controlled surroundings like a ventilation duct, but they are of little use inside African houses, at least in this study. Other brands of hot-wire thermo-anemometers could potentially be more reliable, but they are all constructed from fragile components.

All measurements of ventilation varied within and between nights as they were influenced by the external weather, not least changes in wind intensity and direction. Nonetheless, consistent differences in ventilation between different housing typologies was demonstrated. The three methods measuring $\mathrm{CO}_{2}$ produced broadly similar results and are likely to be a reasonable measure of ventilation in rural structures. The initial validation comparing two identical metal-roofed houses with closed eaves and badly-fitting doors (MCB-MCB) had similar values for $\mathrm{ACH}$ when tested using the three different $\mathrm{CO}_{2}$ methods. The MCB-TOB comparison shows that traditional houses with open eaves and thatch roofs are much better ventilated than metal-roof houses with closed eaves. This finding is concerning since the traditional thatch-roofed houses are being converted to metal-roofed ones across many parts of sub-Saharan Africa [2]. The consequences of the reduced ventilation in metal-roofed houses are that the houses will be hotter and more uncomfortable [8], and thus people are less likely to sleep under a LLIN and therefore be at increased risk of malaria. On the other hand, a high proportion of metal-roofed houses in a settlement may increase the population mortality of mosquitoes resting indoors, reducing the risk of malaria in a community [6]. Method $\mathrm{D}$, designed to measure the natural rise in $\mathrm{CO}_{2}$, failed to increase in the TOB house illustrating that ventilation in 


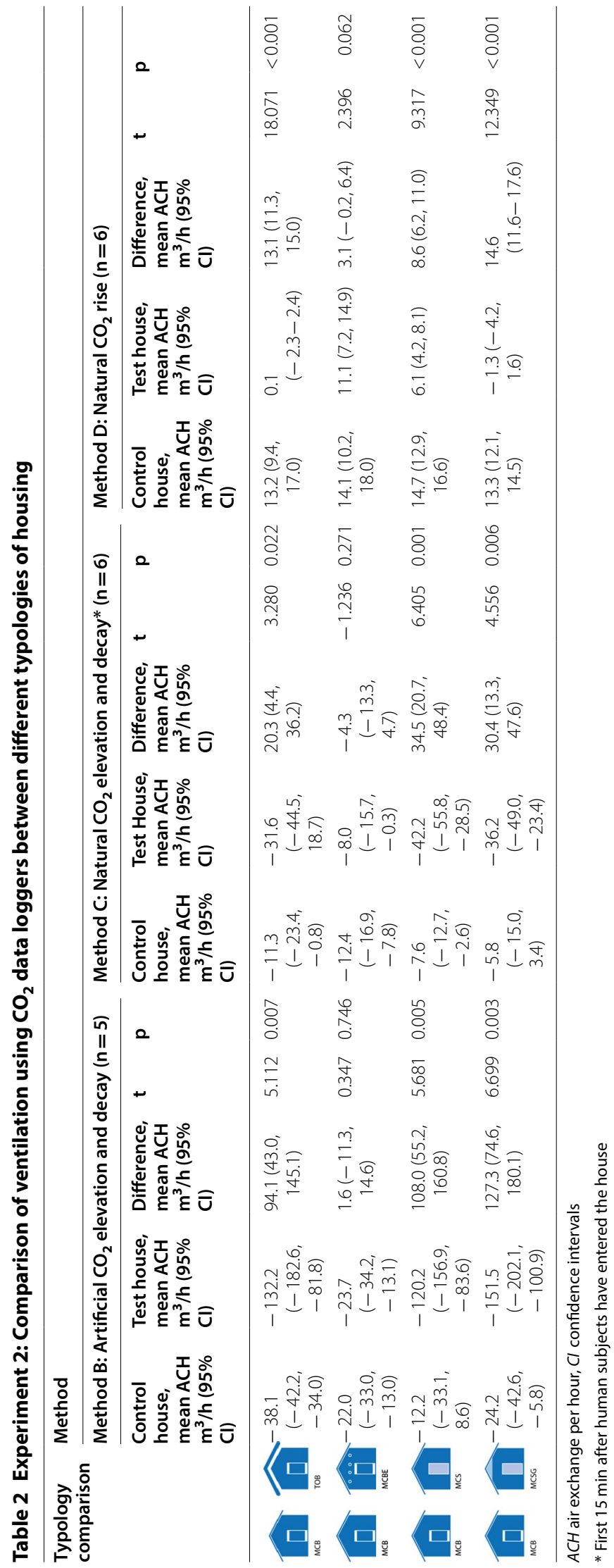




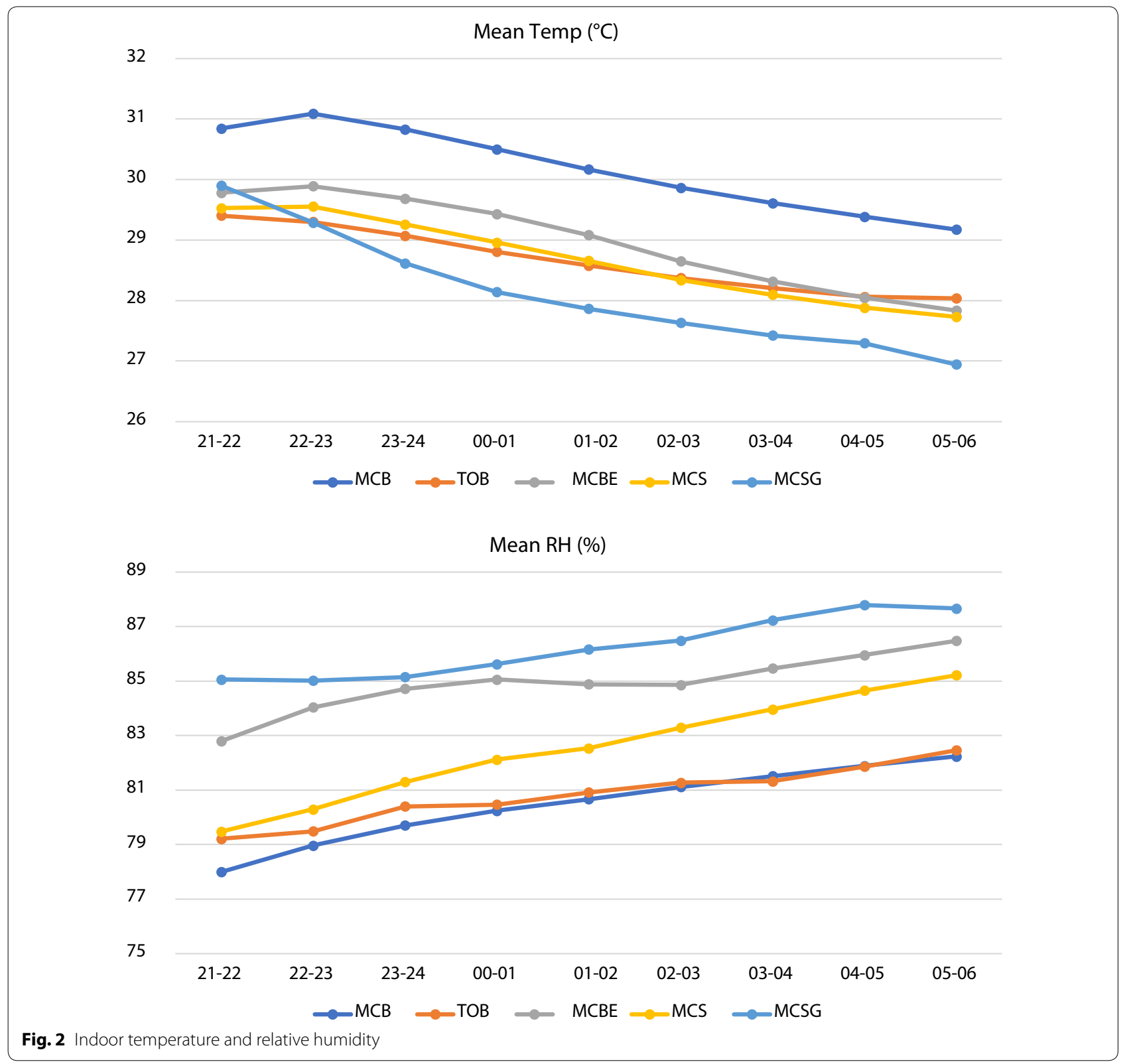

this typology is markedly greater than that experienced in the metal-roof house (Table 3).

Eave tubes are one of the promising new interventions being developed for malaria control in sub-Saharan Africa [28]. The comparison between metal-roofed houses without and with eave tubes (MCB-MCBE) suggest that eave tubes do not increase indoor ventilation as assessed using $\mathrm{CO}_{2}$, although houses with eave tubes were slightly cooler than houses without, suggesting any impact is small. This finding is not surprising since the cross-sectional area of the tubes $\left(0.06 \mathrm{~m}^{2}\right)$ is very small compared to the volume of the building $\left(38 \mathrm{~m}^{2}\right)$, equivalent to two screened windows, measuring $30 \mathrm{~cm} \times 20 \mathrm{~cm}$ on each side of the building. In terms of cross-ventilation this is very little. Although host odours from inside the house may be released through the tubes, the eave tubes do not increase ventilation, leaving indoor comfort unchanged. On the other hand, the MCB-MCS comparison shows that large screened doors will increase ventilation and therefore indoor comfort, and this can be further increased by inserting screened windows in the gable ends of buildings, as seen in the MCB-MCSG comparison. Indeed, in the typology with screened doors and windows, using the natural method for producing $\mathrm{CO}_{2}$ 


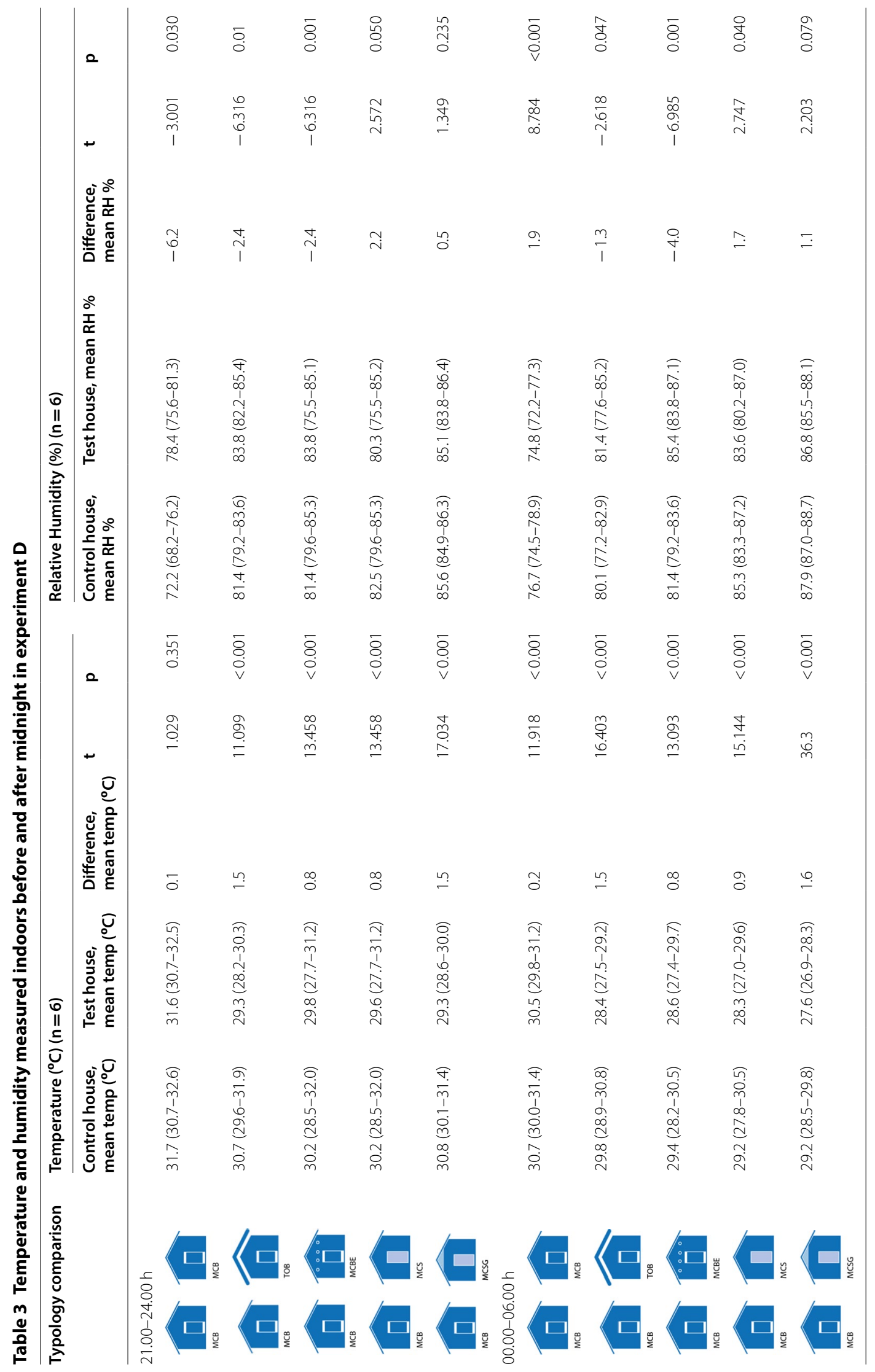


(method D) we could not raise the $\mathrm{CO}_{2}$ concentration indoors in the MSCG house, indicating that this house is in ventilation balance comparable to the traditional thatch-roof houses.

In this study the metal-roofed house with closed eaves was markedly hotter at night than the traditional thatch houses, in agreement with previous studies [8]. Nonetheless, the metal-roofed house could be made cooler by adding screened doors and windows to the house.

In this study, methods to measure ventilation have been evaluated. Knowledge on ventilation in a house could be used to keep the occupants cool and more likely to sleep under a bed net. Another important consideration is to better understand how air moves out of these houses in a more detailed way, as these currents of air disseminate human odours and enable mosquitoes to locate human hosts [29]. Airflow, and the shape of the host odour plume leaving the house can be modelled using Computer Fluid Dynamics (CFD) software [30]. The results of the current experiment will be used to evaluate a future CFD modelling study designed to improve airflow in buildings to keep the occupants comfortable, whilst keeping out mosquitoes.

\section{Conclusion}

This pilot study has identified simple, practical and accurate methods for measuring ventilation in rural African houses. Indoor ventilation is essential in hot and humid environments if people are going to be comfortable and use a bed net at night. Indoor climate is normally only evaluated looking at temperature and humidity leaving out ventilation, the third major component in indoor thermal comfort [19]. This study found that the simplest method for reliably evaluating natural ventilation of a building was to use $\mathrm{CO}_{2}$ data loggers to measure natural concentrations of $\mathrm{CO}_{2}$ decay. In houses that are well ventilated the best way to do this is use artificial sources of $\mathrm{CO}_{2}$ to rapidly raise indoor concentrations, taking care that no one remains inside the house during these measurements.

Roll Back Malaria, United Nations (UN) Development Program and UN Habitat's Housing and Malaria consensus statement [24] has asked 'what architectural features are protective' against malaria? One of the answers is "climatically comfortable houses that allows people to use a LLIN". This study demonstrates that the climatic performance of different house typologies differs a lot in rural Gambia. Traditional houses with open eaves and thatch roofs are much better ventilated than the more modern and now typical metal-roof houses with closed eaves. This could be a major problem as the transformation from thatch to metal is happening all over Africa at a very rapid pace. A metal-roofed house can, however, be made as well ventilated as a thatched-roofed house by allowing airflow through the house by screening the doors and adding a screened window directly under the roof. Better ventilation and higher airflow increased thermal comfort makes it more likely that people will sleep under a LLIN, helping to improve malaria control in hot and humid parts of sub-Saharan Africa.

\section{Supplementary information}

Supplementary information accompanies this paper at https://doi. org/10.1186/s12936-020-03327-0.

Additional file 1: Figure S1. Aerial Photo. Wali Kunda Field Station (13 $34.440^{\prime} \mathrm{N}, 14^{\circ} 55.471^{\prime} \mathrm{W}$ ). North up. Figure S2. House typologies. 1) Metal roof, closed eaves, badly-fitted solid doors, MCB, 2) thatched-roofed house with closed eaves and badly-fitting doors, TOB, 3) Metal roof, closed eaves, badly-fitted solid doors and eave tubes, MCBE, 4) Metal roof, closed eaves, well-fitted ventilated screened door, MCS and 5) Metal roof, closed eaves, well-fitted ventilated screened doors \& ventilated gable ends, MCSG (designed by JK). Figure S3. Photos. 1) Aerial photo, 2) experimental houses seen from north, 3) interior of house with BlowerDoor and eave tubes, 4) exterior with BlowerDoor inserted, 5) custom-made eave tubes 6) roof being replaced, 7) close-up of screened door and 8) ventilated window under roof. Figure S4. BlowerDoor test. Example on output from automated test. Figure S5. ACH estimated using $\mathrm{CO} 2$ data loggers. Test $\mathrm{A}$, Test $B$ and Test $C$.

Additional file 2: Table S1. Summary data of air exchange with different typologies of houses.

\section{Abbreviations}

ACH: Air exchange pr. hour (number); IAS: Indoor air speed (m/s).

\section{Acknowledgements}

We thank the staff of Wali Kunda Field Station for their support during the study. The houses were built by local craftsmen.

\section{Authors' contributions}

JK, MP, MJ and SL conceived and designed the study. The ventilated metalroofed house was designed by JK. The fieldwork was carried out by MY, AS, EJ and MJ, supported by MP, JK and SL. Data analysis was done by JK and SLL. JK and SL wrote the first draft of the manuscript. All authors read and approved the final manuscript.

\section{Funding}

The study was funded by the Sir Halley Stewart Trust. SWL \& MP are supported by the Global Health Trials funded by the MRC-Department of International Development-Wellcome Trust and SWL by the Global Challenges Research Fund.

\section{Availability of data and materials}

The datasets used and/or analysed during the current study are available from the corresponding author on reasonable request.

\section{Ethics approval and consent to participate}

Not applicable.

\section{Consent for publication}

Not applicable.

\section{Competing interests}

The authors declare that they have no competing interests.

\section{Author details}

1 Schools of Architecture, Design and Conservation, The Royal Danish Academy of Fine Arts, Philip de Langes Allé 10, 1435 Copenhagen K, Denmark. 
${ }^{2}$ Medical Research Council Unit, The Gambia at the London School of Hygiene \& Tropical Medicine, Fajara, The Gambia. ${ }^{3}$ Department of Biosciences, Durham University, Durham, UK. ${ }^{4}$ London School of Hygiene \& Tropical Medicine, London, UK. ${ }^{5}$ National Malaria Control Programme, Banjul, The Gambia.

Received: 21 February 2020 Accepted: 7 July 2020

Published online: 31 July 2020

\section{References}

1. United Nations, Department of Economics and Social Affairs. World population prospects : the 2019 revision-key findings and advance tables. 2019.

2. Tusting LS, Bisanzio D, Alabaster G, Cameron E, Cibulskis R, Davies M, et al. Mapping changes in housing in sub-Saharan Africa from 2000 to 2015. Nature. 2019:568:391-4.

3. Bughin J, Chironga M, Desvaux G, Ermias T, Jacobson P, Kassiri O, et al. Lions on the move. II: Realizing the potential of Africa's economies. San Fransico: McKinsey Global Institute; 2016.

4. Tusting LS, Ippolito MM, Willey BA, Kleinschmidt I, Dorsey G, Gosling RD, et al. The evidence for improving housing to reduce malaria: a systematic review and meta-analysis. Malar J. 2015;14:209.

5. Lindsay SW, Emerson PM, Charlwood JD. Reducing malaria by mosquitoproofing houses. Trends Parasitol. 2002;18:510-4.

6. Lindsay SW, Jawara M, Mwesigwa J, Achan J, Bayoh N, Bradley J, et al. Reduced mosquito survival in metal-roof houses may contribute to a decline in malaria transmission in sub-Saharan Africa. Sci Rep. 2019:9:7770.

7. Knudsen J, Seidlein LV. Healthy homes in tropical zones. Improving rural housing in Asia and Africa. Stuttgart: Axel Menges; 2014.

8. Jatta E, Jawara M, Bradley J, Jeffries D, Kandeh B, Knudsen JB, et al. How house design affects malaria mosquito density, temperature, and relative humidity: an experimental study in rural Gambia. Lancet Planet Health. 2018:2:e498-508.

9. Pulford J, Hetzel MW, Bryant M, Siba PM, Mueller I. Reported reasons for not using a mosquito net when one is available: a review of the published literature. Malar J. 2011;10:83.

10. WHO. Achieving and maintaining universal coverage with long-lasting insecticidal nets for malaria control. WHO/HTM/GMP/2017. 2017;20.

11. von Seidlein L, Ikonomidis K, Mshamu S, Nkya TE, Mukaka M, Pell C, et al. Affordable house designs to improve health in rural Africa: a field study from northeastern Tanzania. Lancet Planet Health. 2017;1:e188-99.

12. Chamie G, Wandera B, Luetkemeyer A, Bogere J, Mugerwa RD, Havlir DV et al. Household ventilation and tuberculosis transmission in Kampala, Uganda. Int J Tuberc Lung Dis. 2013;17:764-70.

13. ASTM. ASTM D6245-18. Standard guide for using indoor carbon dioxide concentrations to evaluate indoor air quality and ventilation. West Conshohocken: ASTM International; 2018.

14. Clarke A, Rothery P, Isaac NJB. Scaling of basal metabolic rate with body mass and temperature in mammals. J Anim Ecol. 2010;79:610-9.
15. ASTM. ASTM E741-11. Standard test method for determining air change in a single zone by means of a tracer gas dilution. West Conshohocken: ASTM International; 2017.

16. ASTM. ASTM E779-19. Standard test method for determining air leakage rate by fan pressurization. West Conshohocken: ASTM International; 2019.

17. Standardization IOf. ISO 9972:2015 Thermal performance of buildings, determination of air permeability of buildings, fan pressurization method. Geneva: ISO; 2015.

18. Pinder M, Conteh L, Jeffries D, Jones C, Knudsen J, Kandeh B, et al. The RooPfs study to assess whether improved housing provides additional protection against clinical malaria over current best practice in The Gambia: study protocol for a randomized controlled study and ancillary studies. Trials. 2016;17:275.

19. Fanger PO. Thermal comfort Analysis and applications in environmental engineering. Copenhagen: Danish Technical Press; 1970. p. 244.

20. Gillies MT. The role of carbon dioxide in host-finding by mosquitoes (Diptera: Culicidae): a review. Bull Entomol Res. 1980;70:525-32.

21. Laussmann D, Helm D. Air change measurements using tracer gases: methods and results. Significance of air change for indoor air quality. In: Chemistry, emission control, radioactive pollution and indoor air quality. 2011.

22. Mwesigwa J, Achan J, Di Tanna GL, Affara M, Jawara M, Worwui A, et al. Residual malaria transmission dynamics varies across The Gambia despite high coverage of control interventions. PLoS ONE. 2017;12:e0187059.

23. Craig Millera TK. Testing for Air Leakage: Florida Energy Systems Consortium (FESC); 2015. http://www.myfloridahomeenergy.com/help/library/ contractors-certifications/testing-for-air-leakage/\#sthash.C8cXUBxl.dpbs. Accessed 15 Jan 2020.

24. RBM/UNDP/UN-Habitat. Housing and malaria. Consensus statement Geneva, Switzerland. RBM/UNDP/UN-Habitat. 2015.

25. McWilliams J. Review of air flow measurement techniques. United States; 2002 2002-12-01.

26. ASHRAE. Standard 55-2010. Thermal Environmental Conditions for Human Occupancy. Atlanta, USA, ASHRAE; 2010.

27. Médecins Sans Frontières and Partners In Health. Tuberculosis: Practical guide for clinicians, nurses, laboratory technicians and medical auxiliaries 2014.

28. Knols BG, Farenhorst M, Andriessen R, Snetselaar J, Suer RA, Osinga AJ, et al. Eave tubes for malaria control in Africa: an introduction. Malar J. 2016;15:404

29. Takken W. Synthesis and future challenges: the response of mosquitoes to host odours. Ciba Found Symp. 1996;200:302-12 (discussion 312-20).

30. Bulińska A, Buliński Z. A CFD analysis of different human breathing models and its influence on spatial distribution of indoor air parameters. Comput Assist Meth Engineer Sci. 2017;22:213-27.

\section{Publisher's Note}

Springer Nature remains neutral with regard to jurisdictional claims in published maps and institutional affiliations.

Ready to submit your research? Choose BMC and benefit from

- fast, convenient online submission

- thorough peer review by experienced researchers in your field

- rapid publication on acceptance

- support for research data, including large and complex data types

- gold Open Access which fosters wider collaboration and increased citations

- maximum visibility for your research: over $100 \mathrm{M}$ website views per year

At BMC, research is always in progress.

Learn more biomedcentral.com/submissions 